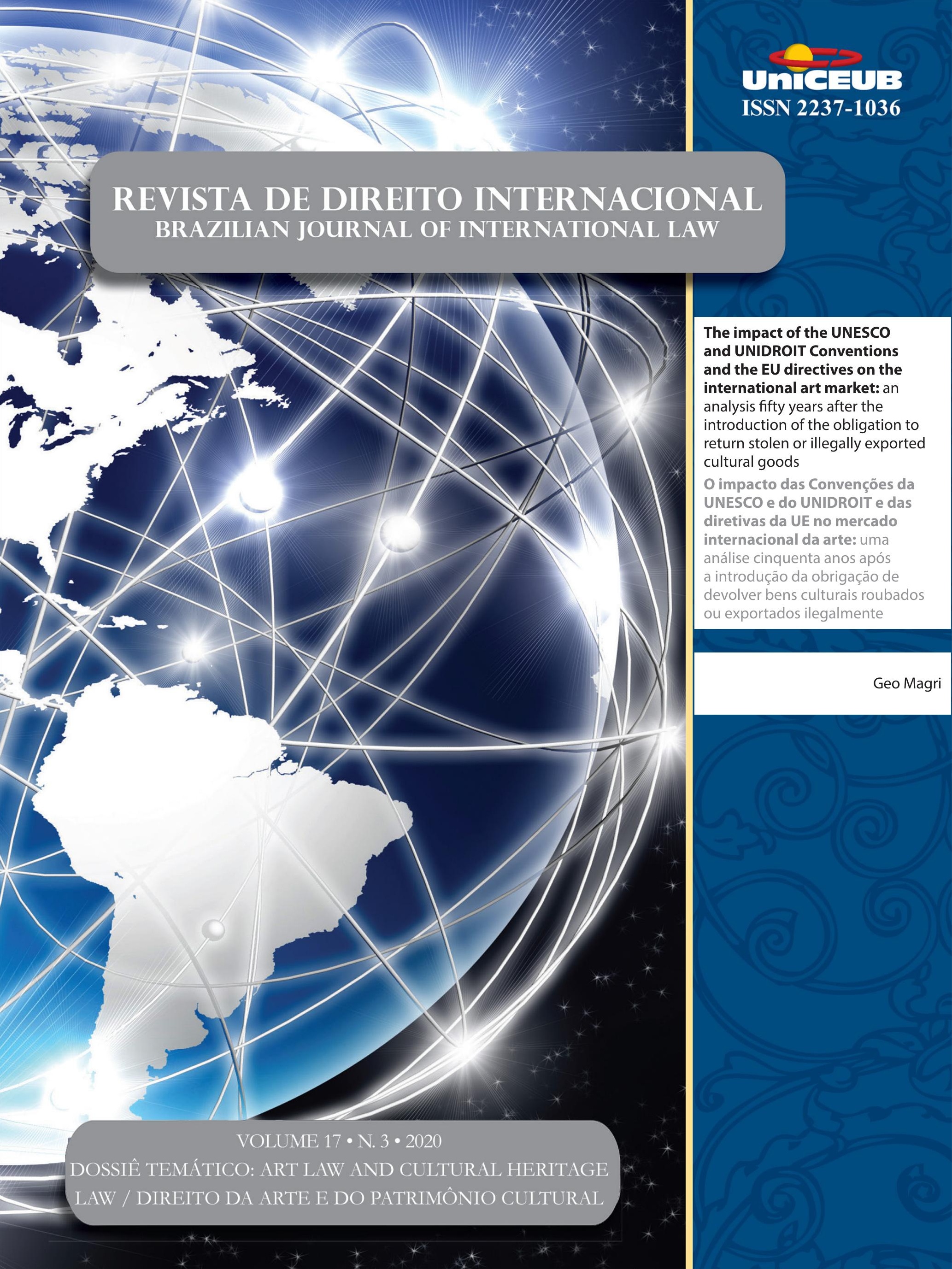




\section{Sumário}

EDITORIAL .20

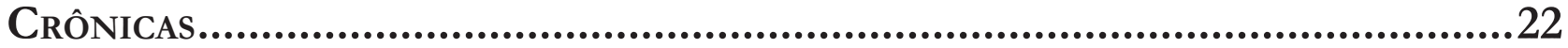

O COSTUME INTERNACIONAL COMO REFORÇO DA OBJEÇÃO BRASILEIRA À CLÁUSULA DO TRATAMENTO JUSTO E EQUITATIVO .24

Leonardo Vieira Arruda Achtschin

O PROCESSO LEGISLATIVO COMO GARANTIA PARA A OBTENÇÃo DO CONSENTIMENTO PRÉVIO DAS COMUnidades quilombolas de AlCÂNTARa

Gabriel de Oliveira Borba

Dossiê temático: Art Law and Cultural Heritage law / Direito da Arte e do Patrimônio cultural - Panorama Geral

Peoples' heritage or States' heritage? sovereignty in the UNESCO mechanism for THE SAFEGUARDING OF INTANGIBLE CULTURAL HERITAGE.

Aliki Gkana

The IMPACT OF THE UNESCO AND UNIDROIT CONVENTIONS AND THE EU DIRECTIVES ON THE INTERNATIONAL ART MARKET: AN ANALYSIS FIFTY YEARS AFTER THE INTRODUCTION OF THE OBLIGATION TO RETURN STOLEN OR ILLEGALLY EXPORTED CULTURAL GOODS 61

Geo Magri

Três pautas em destaque na agenda de diversidade Cultural da Unesco: Ambiente digiTAL, TRATAMENTO PREFERENCIAL E PARTICIPAÇÃO DA SOCIEDADE CIVIL............................76

Danilo Júnior de Oliveira, Maria Carolina Vasconcelos Oliveira e Ana Paula do Val

A 100 YEARS INSTITUTIONALIZED CULTURAL HERITAGE PROTECTION: FROM THE INSTITUTIONALIZED INTERNATIONAL COOPÉRATION INTELLECTUELLE TO THE HUMAN RIGHT TO CULTURAL HERITAGE

Lando Kirchmair 


\section{Aspectos Metodológicos do Direito da Arte e do Patrimônio}

Cultural

A proteção do PATrimônio CULTURAL EM NOVAS PERSPECTIVAS: ESTUdo COMPARAdo ENTRE A Kulturgutschutzgesetz e a Holocaust Expropriated Art Recovery Act of 2016.....111 Ardyllis Alves Soares

ArT-RELATED DispUTES AND ADR METHODS 127 Maria Beatrice Deli e Veronica Proietti

Due Diligence in Art Law and Cultural Heritage Law 150 Lisiane Feiten Wingert Ody

The Reception of Droit de Suite in International Law: Diagnosis and Remedy .... 170 Mickael R. Viglino

Direito da Arte e do Patrimônio Cultural: do Regional ao Local ....... 188

Câmara Cascudo e o legal Design - A Visualidade do Direito entre Provincianismo e GlobalizaÇão 190 Marcilio Toscano Franca Filho

A política da União Europeia no turismo: O turismo cultural e a sustentabilidade do PATRIMONNIO INDUSTRIAL PARA INTEGRAÇÃO DO BLOCO EUROPEU

Maraluce Maria Custódio e Fernando Barotti dos Santos

Diálogo entre la Corte Interamericana de Derechos Humanos y el Tribunal Europeo de Derechos Humanos en torno al Derecho humano a la identidad cultural..223 Juan Jorge Faundes

Digital ART AND THE BELT AND ROAD INITIATIVE: CHALLENGES AND OPPORTUNITIES 257 Dan Wei e Ângelo Rafael

Policing heritage crime in Latin America. .275 Naomi Oosterman e Donna Yates 
The principles of Cultural Heritage Law based on the Polish Law as an example.292 Małgorzata Joanna Węgrzak e Kamil Zeidler

Heritage Protection in INTERNATIONAL LAw AND NATIONAL LAW: INSIGHTS INTO THE CASE OF VIETNAM

Yen Thi Hong Nguyen e Dung Phuong Nguyen

THE APPROPRIATION OF THE CARIOCA INTANGIBLE CULTURAL HERITAGE BY AN ENTREPRENEURIAL LOGIC

Mário Ferreira de Pragmácio Telles

A Propósito del CARÁcter UNIVERSAL DEL aCCESO A LA CULTURA EN INTERNET: UN ANÁlisis DESDE EL PRISMA INTERNACIONAL Y LA EXPERIENCIA DEL ORDENAMIENTO JURÍDICO CUBANO 344 Janny Carrasco Medina

Direito Humanitário e Arte

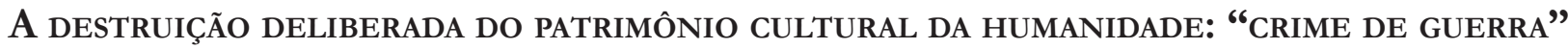
OU "CRIME CONTRA A HUMANIDADE"? Juliette Robichez

Protection OF CULTURAL PROPERTY UNDER INTERNATIONAL HUMANITARIAN LAW: EMERGING TRENDS

Niteesh Kumar Upadhyay e Mahak Rathee

Direito do Mar/Marítimo e Arte.

The underwater Cultural heritage Regime: SOME PROBlems AND POSSible SOlutions. 412 Elina Moustaira

El ROL DEL DERECHO EN LA CONSTRUCCIÓN DEL PATRIMONIO CULTURAL SUBACUÁTICO: APRECiaciones a partirdel estudio del CASo de la Corbeta Inglesa SwifT en Argentina .. 424 Norma Elizabeth Levrand e Nadia Bressan Bernhardt 
INDIGENOUS REFUGEES AND CULTURAL EROSION: POSSIBILITIES AND LIMITS OF INTERNATIONAL REFUGEE AND INDIGENOUS PEOPLES LAW IN THE PROTECTION OF INDIGENOUS CULTURAL EXPRESSIONS RELATED TO TRADITIONAL LAND AND NATIVE LANGUAGE. .440 Rickson Rios Figueira

O RETRATO DE EDMOND BELAMY E A INTERFACE ENTRE ARTE E INTELIGENCIA ARTIFICIAL: POR UMA NOVA DEFINIÇÃo DE AUTORIA E DIREITOS DE PROPRIEDADE INTELECTUAL

Marla Meneses do Amaral Leite Mangiolardo, Patrícia Silva de Almeida e Jonathan Barros Vita

Argumentative aspects of Declaration on the Importance and Value of Universal Museums (2002) 479

Agnieszka Plata

A DestinaÇão dos bens CUlturais EM PROCESSOS PENAIS: A ARTE COMO REPARAÇÃo COLETIVA 488

Inês Virgínia Prado Soares e Otavio Venturini

A Justiça de Pieter Bruegel: direito, violência e a venda nos (nossos) olhos. .501 Rafael Lazzarotto Simioni e Cícero Krupp

Artigos Sobre outros temas

DEVERES INTERNACIONAIS E OBRIGAÇÕES SOCIOAMBIENTAIS PARA EMPRESAS MULTI E TRANSNACIONAIS

Luísa Cortat Simonetti Gonçalves e Adriano Sant'Ana Pedra

Maternidade por substituição: perspectivas da ConferênCia da Haia e suas potenciais INFLUÊNCIAS NO REGRAMENTO BRASILEIRO

Tatiana de A. F. R. Cardoso Squeff e Fernanda Rezende Martins

EL (LARGO) CAMINO DE RECONOCIMIENTO Y EJECUCIÓN DE LAUDOS ARBITRALES DE INVERSIÓN

Thiago Paluma, Ivette Esis e Gabriel Briceño 
A INTERPRETAÇÃo EVOLUTIVA DA CONVENÇÃo AMERICANA SOBRE DiREITOS HUMANOS: UMA REVISÃO DOCUMENTAL DO PERÍODO 1988-2018

Breno Baía Magalhães

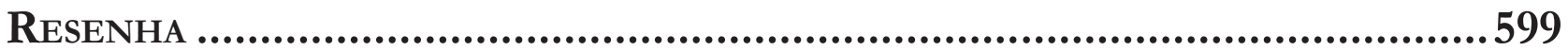

Autonomous Weapons Systems and InTERnATIONAL LAw: A STUDY ON HUMAN-MACHINE INTERACTIONS IN ETHICALLY AND LEGALLY SENSITIVE DOMAINS

Aziz Tuffi Saliba e Lutiana Valadares Fernandes Barbosa 


\title{
The impact of the UNESCO and UNIDROIT Conventions and the EU directives on the international art market: an analysis fifty years after the introduction of the obligation to return stolen or illegally exported cultural goods*
}

\author{
O impacto das Convenções da UNESCO \\ e do UNIDROIT e das diretivas da UE no \\ mercado internacional da arte: uma análise \\ cinquenta anos após a introdução da obrigação \\ de devolver bens culturais roubados ou \\ exportados ilegalmente
}

Geo Magri**

* Recebido em 29/06/2020

Aprovado em 28/02/2021

* Former researcher at the European Legal Studies Institute at the University of Osnabrück, has gained solid experience in projects concerning the harmonization of European private law, also providing advice to the European Parliament and the European Commission. His research activity has focused, in particular, on consumer law, property and rights in rem, cultural goods, entertainment law and limitation. Formerly Vice-President of the Internationale Juristenvereingung, he is a member of several scientific associations, including the Association Henri Capitant and the Deutsch-Italienische Juristenvereinigung. He has lectured in Italy, Germany and Poland and is author of four monographs and more than fifty minor essays published in Italian, English and German. Gastwissenschaftler (Sommersemester 2019) at the European Legal Studies Institute of the University of Osnabrück, he is the Italian referent for the international project Gemeineuropäisches Personenrecht coordinated by Prof. Dr. Dr. h. c. mult. Christian von Bar and financed by the Deutsche Forschungsgemeinschaft (DFG). Individual partner of the 1995 UNIDROIT Convention Academic Project and arbitrator at the Court of Arbitration for Art (CAfA) in The Hague (The Netherlands). He is currently a Assistant professor of private law at the Law Department of the University of Insubria.

E-mail: geo.magri@uninsubria.it

\section{Abstract}

The purpose of this study is to analyse the relationship between international conventions and European Union law on the restitution of cultural goods, highlighting how the adoption of rules on this matter has produced a real change of mentality in the international community, which is now much more careful in monitoring the lawful movement of cultural goods. The effects of such a change of mentality are evident: museums today are much more careful in verifying the origin of the objects they buy and are more inclined to return the items that are part of their collections, but that have been illegally exported from their country of origin; moreover, the ICOM has adopted a code of ethics to ensure the transparency of acquisitions. Merchants and collectors have also begun to promote a serious reflection on their role as guarantors in the conservation of cultural heritage.

Keywords: Cultural property. Restitution. Return. Good Faith. Due Diligence.

\section{Resumo}

O objetivo deste estudo é analisar a relação entre as convenções internacionais e o direito da União Europeia sobre a restituição de bens culturais, destacando como a adoção de normas nesta matéria produziu uma verdadeira mudança de mentalidade na comunidade internacional, que agora é muito mais cuidadosa em monitorar o movimento legal de bens culturais. Os efeitos dessa mudança de mentalidade são evidentes: os museus hoje são muito mais cuidadosos na verificação da origem dos objetos que compram e estão mais inclinados a devolver os itens que fazem parte de suas coleções, mas que foram exportados ilegalmente de seu país da origem; além dis- 
so, o ICOM adotou um código de ética para garantir a transparência das aquisições. Comerciantes e colecionadores também começaram a promover uma reflexão séria sobre seu papel como fiadores da conservação do patrimônio cultural.

Palavras-chave: patrimônio cultural, propriedade cultural, boa-fé, restituição, retorno, UNESCO, UNIDROIT

\section{Introduction}

In 2020 we celebrate the 50th anniversary of the 1970 UNESCO Convention on the Means of Prohibiting and Preventing the Illicit Import, Export and Transfer of Ownership of Cultural Property and the 25th anniversary of the 1995 UNIDROIT Convention on Stolen or Illegally Exported Cultural Objects. The two Conventions have a significant historical importance because they mark the introduction of a previously unknown legal principle: the obligation to return stolen or illegally exported cultural goods to their country of origin.

The need to return cultural or illicitly exported goods initially arose with regard to armed conflicts. Already at the end of the Napoleonic era the restitution of the works of art plundered by the French army was organized and Pope Pius VII charged Antonio Canova to recover the works of art looted in Rome and in the other cultural centres of the Papal State ${ }^{1}$.

Starting from the UNESCO Convention of 1970, however, the obligation to return art works is extended to works illegally transferred by a State, even in the absence of an armed conflict. The Convention introduces a general principle according to which the removal of a cultural property from the individual State must be considered illegal and the international community must take action to encourage the return of cultural heritage to the place where it was created. The principle was also implemented by the UNIDROIT Convention of 1995 and by the European Community, which in 1993, adopted a directive (directive number $93 / 7$, on the return of cultural goods) ${ }^{2}$, which was largely influenced by

\footnotetext{
See GABBRIELLI, V. Patrimoni contesi: gli stati italiani e il recupero delle opere d'arte trafugate in Francia: storia e fonti: 1814-1818. Firenze, 2009.

2 Council Directive 93/7/EEC, Directive of 15 March 1993, on
}

the preparatory works of the UNIDROIT Convention and which, in its turn, influenced the final text of the UNIDROIT Convention. The Directive $93 / 7$ was later replaced by the Directive 2014/603 , which introduces some substantive changes to the regulatory framework and attempts to correct certain weaknesses found in the application of the 1993 Directive.

The purpose of this study is to analyse the relationship between international conventions and European Union law on the restitution of cultural goods, highlighting how the adoption of rules on this matter has produced a real change of mentality in the international community ${ }^{4}$, which is now much more careful in monitoring the lawful movement of cultural goods. The effects of such a change of mentality are evident: museums today are much more careful in verifying the origin of the objects they buy and are more inclined to return the items that are part of their collections, but that have been illegally exported from their country of origin; moreover, the ICOM has adopted a code of ethics to ensure the transparency of acquisitions ${ }^{5}$. Merchants and collectors have also begun to promote a serious reflection on their role as guarantors in the conservation of cultural heritage, as demonstrated by the Responsible Art Market Initiative, created in a traditionally problematic country like Switzerland ${ }^{6}$.

the return of cultural objects unlawfully removed from the territory of a Member State, OJ L 74, 27.3.1993, p. 74.

3 Directive 2014/60/EU of the European Parliament and of the Council of 15 May 2014 on the return of cultural objects unlawfully removed from the territory of a Member State and amending Regulation (EU) No. 1024/2012, OJ L 159, 28.05.2014, p. 1.

4 See SALIBA, A.; FABRIS, A. L. O retorno de bens culturais. Revista de Direito Internacional, v. 14, n. 2, p. 491, 2017.

5 See Art. 2.3 ICOM Code of ETHICS for Museums (https:// icom.museum/wp-content/uploads/2018/07/ICOM-code-Enweb.pdf): «Provenance and Due Diligence Every effort must be made before acquisition to ensure that any object or specimen offered for purchase, gift, loan, bequest, or exchange has not been illegally obtained in, or exported from its country of origin or any intermediate country in which it might have been owned legally (including the museum's own country). Due diligence in this regard should establish the full history of the item since discovery or production».

6 With reference to the role of ethical codes, see GRAZIADEI, M.; PASA, B. in A. JAKUBOWSKI, K. HAUSLER, F. FIORENTINI (ed.). Cultural Heritage in the European Union: A Critical Inquiry into Law and Policy. Leiden - Boston, 2019. p. 88. 


\section{The introduction of the duty to return cultural goods: the UNESCO Convention of 1970}

As we have already pointed out, the general principle that illicitly exported cultural goods must be returned to their country of origin finds its origin in international Conventions ${ }^{7}$. It was in fact set out, for the first time, by the UNESCO Convention of 1970 and subsequently reaffirmed and strengthened by the UNIDROIT Convention of 1995 and by Directive 93/7/EEC (later replaced by Directive 2014/60/EU).

The intent of the international conventions was and is, therefore, merely protectionist in respect to the cultural heritage of each Member State. This point must be duly stressed, as it marks a difference from EC/EU legislation which, on the other hand, has as its main purpose to reconcile the principle of free movement with conservation of the cultural heritage of each Member State.

From the point of view of private law, it should be pointed out that one of the main results of the adoption of these Conventions has been to limit the applicability of the rule en fait de menbles possession vaut titre in force in all the main European continental legal syste$\mathrm{ms}^{8}$. This private-law effect arises from Article 7 (b)(ii) of the 1970 UNESCO Convention, that provides that an object of cultural property stolen from a museum or a religious or secular public monument must be returned to the state from which it was removed. The return can only be claimed if the stolen object was listed in the inventory of the institution and if it was imported into the foreign State after the Convention entered into force in both Contracting States. The Convention provides that any "innocent purchaser", or anyone who can claim a valid title to the stolen cultural property is entitled to receive fair compensation?. In this respect, it should be

See S. TURNER, S. Das Restitutionsrecht des Staates nach illegaler Ausfubr von Kulturgütern. De Gruyter, 2002 and SALIBA, A.; FABRIS, A. L. O retorno de bens culturais. Revista de Direito Internacional, v. 14, n. 2, p. 494, 2017.

8 See MAGRI, G. Acquisto a non domino e beni culturali. Riv. dir. civ., p. 741, 2013; MAGRI, G. Directive 2014/60/EU and Good Faith Acquisition of Cultural Goods. in Italy. In: PINTON, S.; ZAGATO, L. (ed.). Sapere l'Europa, sapere d'Europa Cultural Heritage. Scenarios, 2015-2017. v. 4. p. 227.

9 See FRIGO, M. Circulation des biens culturels, détermination de la loi applicable et méthodes de règlement des litiges. Recueil des Cours de l'Académie de la Haye, , v. 375, p. 267, 2014. noted that the report of the Special Committee of Experts, which finalized the text, spoke of compensation to be paid "to a bona fide purchaser", so that it seems that this should be interpreted as an "innocent" purchaser, or even better, a due diligent purchaser ${ }^{10}$. A similar rule has also been included in the UNIDROIT Convention of 1995 and in Directives 93/7 and 2014/60.

As already pointed out, the first Convention aimed at regulating the return of illicitly exported cultural goods was drawn up by UNESCO (Convention on the measures to be taken to prohibit and prevent the illicit import, export and transfer of ownership of cultural goods) ${ }^{11}$. The Convention is based on "three pillars": the first concerns preventive measures at national level to effectively combat illicit trafficking in cultural goods; the second deals with restitution; and the third concerns cooperation between States ${ }^{12}$.

The UNESCO Convention entered into force on the $24^{\text {th }}$ April 1972 and prohibits the transfer of ownership, exporting and importing of goods, listed in Article 1, which have historical, archaeological, literary, artistic and scientific relevance ${ }^{13}$. The prohibition, however, is not absolute: each Contracting State is responsible for determining which transactions relating to property lo-

10 Originally the text mentioned the Latin expression bona fide. However, when Article 7 was reviewed on the US draft proposal, the expression bona fide was left out, because it did not seem to be a legal term of Common Law. See O'KEEFE, P. J. Commentary on the UNESCO 1970 Convention on Illicit Traffic. Leicester 2000. p. 67 and M. SCHNEIDER, M. The 1995 UNIDROIT Convention: An Indispensable Complement to the 1970 UNESCO Convention and an Inspiration for the 2014/60/EU Directive. Santander Art and Culture Law Review, p. 152, 2/2016.

11 FRIGO, M. La circolazione internazionale dei beni culturali, Diritto Internazionale, Diritto Comunitario e Diritto Interno. II ed. Milan, 2007. p. $8 \mathrm{ff}$. and J. SPRECHER, J. Beschränkungen des Handels mit Kulturgut und die Eigentumsgarantie. De Gruyter, 2004. p. 57.

12 DELEPIERRE, S.; SCHNEIDER, M. Ratification and Implementation of International Conventions to Fight Illicit Trafficking of Cultural Property. In: DESMARAIS, F. (ed.). Countering Illicit Traffic in Cultural Goods: The Global Challenge of Protecting the World's Heritage, ICOM International Observatory on Illicit Traffic in Cultural Goods. Paris, 2015. p. 130-132.

13 Article 5(b): «To ensure the protection of their cultural property against illicit import, export and transfer of ownership, the States Parties to this Convention undertake, as appropriate for each country, to set up within their territories one or more national services, where such services do not already exist, for the protection of the cultural heritage, with a qualified staff sufficient in number for the effective carrying out of the following functions: [...] (b) establishing and keeping up to date, on the basis of a national inventory of protected property, a list of important public and private cultural property whose export would constitute an appreciable impoverishment of the national cultural heritage». 
cated in its territory and identified by the Convention may be considered lawful and which may not ${ }^{14}$. This shows that the purpose of the Convention is to provide individual Contracting States with an instrument to protect their cultural heritage, rather than to protect a supposed international cultural heritage ${ }^{15}$.

Signing the Convention gives rise to the obligations set out in art. 7. These obligations consist of preventing the acquisition by museums of goods unlawfully exported from another Member State ${ }^{16}$, prohibiting the importation of cultural goods which (after the entry into force of the Convention) have been stolen from a museum or other public, civil or religious institution, and, finally, returning, at the request of the State of origin, any stolen or unlawfully exported cultural goods.

The Convention also provides for the obligation to take all necessary measures to prevent and repress the unlawful movement of cultural goods by facilitating their return to the State of origin.

Article 13 imposes certain obligations aimed at preventing and, if possible, eliminating the effects of the illicit circulation of cultural goods. In particular, States are required to adopt appropriate legislation to prevent the transfer of ownership of cultural goods and their illicit import or export; to facilitate the return of illegally exported goods to those who are entitled to them as soon as possible; to allow an action for claiming ownership of lost or stolen cultural goods by or on behalf of the owner and to recognise the right of each Member State to classify and declare inalienable certain cultural objects which, for that reason, cannot be exported, facilitating their recovery if the export has nevertheless taken place.

The ambitious objectives of the Convention were basically two: firstly, to prevent the illicit movement of cultural goods and, secondly, to impose an obligation on each State to cooperate so that the State of origin

\footnotetext{
14 See. FRIGO, M. La circolazione internazionale dei beni culturali, $\mathrm{Di}$ ritto Internazionale, Diritto Comunitario e Diritto Interno. II ed. Milan, 2007. p. 9.

15 According to the Convention: «Considering that cultural property constitutes one of the basic elements of civilization and national culture, and that its true value can be appreciated only in relation to the fullest possible information regarding its origin, history and traditional setting»).

16 The Convention has been successful and currently includes 142 countries. http://www.unesco.org/eri/la/convention. asp? $\mathrm{KO}=13039$ \&language $=\mathrm{E}$
}

can recover the goods unlawfully exported from its territory ${ }^{17}$.

However, the evidences show that these objectives were not achieved and the Convention did not fulfil the expectations. The reasons for its failure lie mainly in the fact that it does not provide for remedies for the violation of its provisions, revealing itself ineffective because of its generality in formulating principles that are not assisted by appropriate sanctions that make them enforceable ${ }^{18}$. More specifically, the academic literature has identified as the main reason for the failure of the Convention, the inadequate regulation of the return procedure and the difficulty that some States have had in overcoming internal civil law rules such as, for example, the one protecting the purchaser in good faith by virtue of the principle possession vaut titre ${ }^{19}$.

The unsuccessful outcome of the Convention did not mean the downfall of its ambitious objectives. At European and international level, efforts have been made to make the obligations contained in the Convention more effective, leading to Directive $93 / 7$ and to the UNIDROIT Convention of 1995.

\section{The need to make the UNESCO Convention more effective: The UNIDROIT Convention of 1995}

The 1995 UNIDROIT Convention was essentially the result of a twofold need. First of all, it was a reflection on the necessity to harmonise the issues of private law covered by the 1970 UNESCO Convention ${ }^{20}$.

\footnotetext{
17 According to the Convention: «it is essential for every State to become increasingly alive to the moral obligations to respect its own cultural heritage and that of all nations».

18 FRIGO, M. La circolazione internazionale dei beni culturali, Diritto Internazionale, Diritto Comunitario e Diritto Interno. II ed. Milan, 2007. p. 12.

19 FRIGO, M. La circolazione internaz̨ionale dei beni culturali, Diritto Internazionale, Diritto Comunitario e Diritto Interno. II ed. Milan, 2007. p. 13, according to which Article 7. b. ii. of the Convention is not formulated with sufficient clarity. Extremely significant on this point is the judgment of the Italian Supreme Court of 23 November 1995, No 12166, in Foro it., 1996, I, 907 ff., which rejected, 17 years after the ratification of the Unesco Convention by Italy, the request, made by the French Ministry of Cultural Heritage, to return some tapestries stolen from the Palace of Justice in Riom and subsequently sold a non domino in Italy.

20 SCHNEIDER, M. The 1995 UNIDROIT Convention: An Indispensable Complement to the 1970 UNESCO Convention and an
} 
Among all the private law issues raised by the 1970 UNESCO Convention, the central one was its impact on the existing rules of national law regarding the protection of a bona fide purchaser. Although the provision in Article 7(b)(ii) was drafted taking into account the rules of civil law, the final text, "watered down" by subsequent amendments ${ }^{21}$, required further clarification to allow its adaptation to national legal systems ${ }^{22}$.

Secondly, the already mentioned limited results achieved by the 1970 UNESCO Convention led the International Institute for the Unification of Private Law, in collaboration with UNESCO itself, to study new uniform rules on the return and restitution of cultural property $^{23}$. The Institute, assisted by renowned experts and influenced by Directive 93/7/EC, adopted, in 1995, the "Convention on stolen or illegally exported cultural objects", signed in Rome on 24 June 1995, to offer a uniform core of rules.

Inspiration for the 2014/60/EU Directive. Santander Art and Culture Law Review, p. 152, 2/2016 and SALIBA, A.; FABRIS, A. L. O retorno de bens culturais. Revista de Direito Internacional, v. 14, n. 2, p. 499, 2017.

21 O'KEEFE, P. J. Commentary on the UNESCO 1970 Convention on Illicit Traffic. Leicester 2000. p. 57.

22 SCHNEIDER, M. The 1995 UNIDROIT Convention: An Indispensable Complement to the 1970 UNESCO Convention and an Inspiration for the 2014/60/EU Directive. Santander Art and Culture Law Review, p. 153, 2/2016.

23 See KOWALSKI, W. Ratification of the 1995 UNIDROIT Convention on Stolen or Illegally Exported Cultural Objects, in Light of Directive 2014/60/UE on the Return of Cultural Objects Unlawfully Removed from the Territory of a Member State: The Perspective of Poland. Santander Art and Culture Law Review, p. 165, 2/2016; BERGE, J.S. La Convention d'UNIDROIT sur les Biens Culturels: Retour sur un Texte Majeur dans la Lutte Contre un Fait International Illicite de Circulation. Uniform Law Review, v. 20, Issue 4, p. 535, 2015; PROTT, L. V. The UNIDROIT Convention on stolen or illegally exported cultural objects - Ten Years On, in Uniform Law Review. Revue de droit uniforme, p. 215, 2009; CARDUCCI, G. Complémentarité entre les Conventions de l'UNESCO de 1970 et d'UNIDROIT de 1995 sur les biens culturels. Uniform Law Review / Revue de droit uniforme, v. 11, p. 93, 2006; SALVADORI, M. Profili internazionalistici. In: I nuovi contratti nella prassi civile e commerciale, a cura di Cendon. Turin: Beni culturali, 2003. v. VII. p. 401; FRIGO, M. La circolazione internazionale dei beni culturali, Diritto Internazionale, Diritto Comunitario e Diritto Interno. II ed. Milan, 2007, FRIGO, M. La Convenzione dell'Unidroit sui beni culturali rubati o illecitamente esportati. Riv. dir. int. priv e proc., p. 435, 1996; GARDELLA, A. Nuove prospettive per la protezione internazionale dei beni culturali: la Convenzione dell'UNIDROIT del 24 giugno 1995. Dir. Comm. Int., p. 997, 1998; JAYME, E.; WAGNER, F. D. Kulturgüterschutz und Privatrecht: Die UNIDROIT-Konvention von 1995. Tagung des Ludwig Boltzmann Instituts für Europarecht. Wien, IPrax, v. 17, p. 140, 1997 and CARDUCCI, G. La restitution internationale des biens culturels et des objets d'art. Droit commun, Directive CEE, Convention de l'UNESCO et d'UNIDROIT. Paris: LGDJ, 1997.
Article 1 of the Convention clarifies that the Convention applies: «to claims of an international character for: (a) the restitution of stolen cultural objects; (b) the return of cultural objects removed from the territory of a Contracting State contrary to its law regulating the export of cultural objects for the purpose of protecting its cultural heritage (hereinafter "illegally exported cultural objects» ${ }^{24}$. For the purposes of the Convention, any property shall be considered to be cultural if it «on religious or secular grounds» shows an «importance for archaeology, prehistory, history, literature, art or science» and belongs «to one of the categories listed in the Annex to this Convention» (art. 2).

It should be pointed out that Article 1 expressly mentions the international character of the restitution claim. It will therefore be necessary and sufficient for the applicability of the Convention that the cultural object has been stolen or unlawfully transferred from the country of origin to another State. Concerning this point, there is a difference from former international practice. Previously, in fact, the restitution concerned the exit of the cultural good from the territory of the State of origin in violation of national rules, while the return regarded the exit of the cultural good in the absence of rules on circulation or in case of legal exit from the State of origin ${ }^{25}$. The Convention, while adopting the concepts of restitution and return, uses them much more restrictively. The restitution concerns only stolen goods, whereas the return refers to all cases where the goods have left the Contracting State in breach of its internal rules.

It may seem unusual that, unlike Directive 93/7, the Convention does not provide for the definition of the terms adopted. This choice was made because it was contested by some delegations at the drafting stage. The omission seems certainly open to criticism, but it is in part justified by the intention to allow national courts greater discretion in interpreting the provisions ${ }^{26}$.

With regard to stolen cultural goods, the problem was to balance the interests of the bona fide purchaser of the stolen property with those of the previous owner.

\footnotetext{
24 See MARLETTA, M. La restituzione dei beni culturali, Normativa comunitaria e Convenzione Unidroit. Padova, 1997. p. 132.

25 For example, it is possible to think of cases in which goods were exported from one state to another following a war or during the colonial period or for a loan.

26 See FRIGO, M. La circolazione dei beni culturali nel diritto europeo: limiti e obblighi di restituzione. Napoli, 2011. p. 33.
} 
The rules on a non-domino purchases are not uniform across all jurisdictions ${ }^{27}$. There are countries like Italy that offer a wide protection to the purchaser in good faith at the expense of the owner, even in the case of stolen goods (see art. 1153 c.c.) ${ }^{28}$, other legal systems (e.g. France and Germany ${ }^{29}$ ) which limit protection to goods whose possession has not been lost unintentionally and others that do not provide any kind of protection. This is the case, for example, of the Portuguese and English legal system, where, by virtue of the nemo dat quod non habet rule, the dispossessed owner normally prevails over the bona fide purchaser ${ }^{30}$.

The Convention adopts a compromise solution providing (art. 3 par. 1) that «the possessor of a cultural object which has been stolen shall return it»; on the other hand, if he proves his due diligence at the time of purchase, he shall be paid fair compensation: «The possessor of a stolen cultural object required to return it shall be entitled, at the time of its restitution, to payment of fair and reasonable compensation provided that the possessor neither knew nor ought reasonably to have known that the object was stolen and can prove that it exercised due diligence when acquiring the object» (art. 4 par. 1) ${ }^{31}$. Evidences of due diligence are, as Article 4(4) makes clear, «all the circumstances of the acquisition, including the character of the parties, the price paid, whether the possessor consulted any reasonably accessible register of stolen cultural objects, and any other relevant information and documentation which it could reasonably have obtained, and whether the possessor consulted accessible agencies or took any other step that a reasonable person would have taken in the circumstances».

\footnotetext{
27 SIEHR, K. Vereinheitlichung des Mobiliarsachenrechts in Europa, insbesondere im Hinblick auf Kulturgüter. Rabels Zeitschrift für ausländisches und internationales Privatrecht, p. 454, 1995.

28 See. MAGRI, G. Acquisto a non domino e beni culturali. Riv. dir. civ., p. 741, 2013 and MENGONI, L. Gli acquisti a non domino. Milan, 1994. p. $75 \mathrm{ff}$.

29 MENGONI, L. Gli acquisti a non domino. Milan, 1994. p. 75 ff.

30 See VON BAR, C. Gemeineuropäisches Sachenrecht. Munich, 2019. v. 2. p. 450 .

31 See the so called Goldberg case (Autocephalous Greek-Orthodox Church of Cyprus and the Republic of Cyprus vs. Goldberg and Feldman Fine Arts Inc., 917 F.2d 278, United States Court of Appeals, 7th Cir. 1990, decisione del 24 ottobre 1990) commented by BYRNE-SUTTON, Q. The Goldberg Case: A Confirmation of the Difficulty in Acquiring Good Title to Valuable Stolen Cultural Objects. International Journal of Cultural Property, p. 151 ,1992, 1 ${ }^{\text {st. }}$; MIUR WATT, O. La revendication internationale des biens culturels: à propos de la décision américaine Eglise Autocéphale. Rev. crit. droit int. privé, p. 1, 1992.
}

To determine the existence of rights in rem in respect of the goods covered by the restitution claim, reference should be made to the lex originis ${ }^{32}$, i.e. the law of the State of origin of the cultural good, and not to the lex rei sitae generally adopted as a connecting factor in private international law $^{33}$. The solution follows the one already adopted by the 1991 Basel Resolution of the Institut de Droit International on the sale of artworks, which had largely dealt with the problems arising from the application of the general connecting factor of the lex rei sitae also in the field of rights in rem relating to cultural property ${ }^{34}$. The reason why it was decided to use the lex originis instead of the lex loci rei sitae is linked to the difficulties in applying Article 7 of the 1970 UNESCO Convention in the legal systems protecting the acquisition in good faith of movable property ${ }^{35}$.

It could be disputed that the reference to the lex originis might raise some coordination difficulties with the law applicable to the contract under which the goods were purchased after the unlawful exportation ${ }^{36}$ and

32 See SYMEONIDES, S. C. Choice of Law Rule for Conflicts Involving Stolen Cultural Property. Vanderbilt Journal of Transnational Law, p. 1177, 2005. p. 1183 where he proposes to determine the applicable law through the following general rule: «Except as otherwise provided by an applicable treaty or international or interstate agreement, or statute, the rights of parties with regard to a corporeal thing of significant cultural value (hereinafter «thing») are determined as specified below. A person who is considered the owner of the thing under the law of the state in which the thing was situated at the time of its removal to another state shall be entitled to the protection of the law of the former state (state of origin), except as specified below. The owner's rights may not be subject to the less protective law of a state other than the state of origin, (a) unless: (i) the other state has a materially closer connection to the case than the state of origin; and (ii) application of that law is necessary in order to protect a party who dealt with the thing in good faith after its removal to that state; and (b) until the owner knew or should have known of facts that would enable a diligent owner to take effective legal action to protect those rights».

33 SALVADORI, M. Profili internazionalistici. In: I nuovi contratti nella prassi civile e commerciale, a cura di Cendon. Turin: Beni culturali, 2003. v. VII. p. 411.

34 SALVADORI, M. Profili internazionalistici. In: I nuovi contratti nella prassi civile e commerciale, a cura di Cendon. Turin: Beni culturali, 2003. v. VII. p. 411.

35 SALVADORI, M. Profili internazionalistici. In: I nuovi contratti nella prassi civile e commerciale, a cura di Cendon. Turin: Beni culturali, 2003. v. VII. p. 411.

36 See JAYME, E. Internationaler Kulturgüterschutz: Lex originis oder lex rei sitae. Tagung. Heidelberg, in IPrax, n. 10, p. 347, 1990. and JAYME, E. Globalization in Art Law: Clash of Interests and International Tendencies. Vanderbilt Journal of Transnational Law, p. 928, 2005. p. 937 where he observes: «There are, of course, situations where public interests are not involved or are less significant. When an artwork is stolen and two persons claim ownership, the 
to which the lex loci rei sitae is applicable. It should be noted, however, that this law cannot be taken into account because, if the purchase was made after the theft or illicit export, it will be set aside and the purchaser is entitled, if he acted with due diligence, only to claim for fair compensation.

The claim for the restitution of the goods must be submitted within three years from the time the claimant discovered the place where the asset is located and has identified its owner. The restitution cannot be claimed after 50 years (which may be extended by the laws of the individual States, ex. art. 3 par. $5^{37}$ ) from the date of the theft (art. 3 par. $3^{38}$ ).

The limitation period for bringing an action does not apply to the most important cultural goods belonging to the cultural heritage of the member States, for which there is no limitation period (Article 3(4)) ${ }^{39}$. Given the generality of the rule, both the member State and the private individual materially dispossessed of the property ${ }^{40}$ are entitled to bring an action for restitution.

question arises as to whose private interests should prevail those of the former owner or those of the innocent buyer. The answers of the legal systems vary. These differences have generated special conflicts problems in international situations. In private international law, the lex situs at the time of acquisition, and more recently, the law of the lex originis (the country of origin) have emerged as solutions for choice of law. In the European Community, Article 12 of the directive $93 / 7 / \mathrm{EEC}$ concerning the restitution of cultural property seems to favor the lex originis while, in general, the lex rei sitae prevails».

37 According to art. 3.5: «Notwithstanding the provisions of the preceding paragraph, any Contracting State may declare that a claim is subject to a time limitation of 75 years or such longer period as is provided in its law. A claim made in another Contracting State for restitution of a cultural object displaced from a monument, archaeological site or public collection in a Contracting State making such a declaration shall also be subject to that time limitation».

38 According to art. 3.3 «Any claim for restitution shall be brought within a period of three years from the time when the claimant knew the location of the cultural object and the identity of its possessor, and in any case within a period of fifty years from the time of the theft».

39 Some States had suggested to exclude limitation periods for actions for restitution from the Convention. However, this opinion was not successful and the only exception to the limitation period is provided for in Article 3.4: «However, a claim for restitution of a cultural object forming an integral part of an identified monument or archaeological site, or belonging to a public collection, shall not be subject to time limitations other than a period of three years from the time when the claimant knew the location of the cultural object and the identity of its possesson». See MAGRI, G. La circolarione dei beni culturali nel diritto europeo: limiti e obblighi di restituzione. Napoli, 2011. p. 38.

40 According to the Rapport Explicatif of the Convention «La personne du demandeur n'est pas ici spécifiée: on notera que l'action en
This is a relevant difference between the Convention and the EU Directive, which allows only the Member State to take legal action.

The second part of the Convention is devoted to the regulation of illicitly exported cultural goods, i.e. the regulation of those goods which have left the State of origin unlawfully or which, despite having left legitimately, have not returned to the State of origin on time and in the manner provided for. It is therefore necessary for all the acceding States to adopt internal rules on the export and protection of cultural goods. The right to apply for the return of unlawfully exported goods, unlike in the case of stolen goods, lies solely with the Member States (Article 5(1)). However, similarly to what happens with stolen goods, if the goods have been purchased by a third party in good faith, a fair compensation will have to be paid to him and, also in this case, he will be charged with the proof of having purchased with due diligence.

The UNIDROIT Convention entered into force on $1^{\text {st }}$ July 1998 and has been signed or has been ratified by 48 States. These are mainly so-called "exporting" States ${ }^{41}$. These are countries whose cultural heritage is continually endangered by illicit trade and which, therefore, had, in general, already adopted quite advanced legislation with regard to the protection and preservation of cultural property. The fact that the 'importing' countries - where trade in cultural goods is almost unrestricted and which on several occasions have shown their reluctance to protect this market - have not signed or ratified the Convention is a sign that demonstrates its effectiveness in protecting cultural heritage.

\section{The relationship between Directive 93/7 and the UNIDROIT Convention}

As has already been pointed out, when the UNIDROIT Convention was drafted, Directive $93 / 7$ was the model to look to and draw inspiration from, given

restitution - qui sera portée devant les tribunaux ou autres autorités compétentes visées aux articles 8 et 16 -, peut être intentée aussi bien par une personne privée qui a été dépossédée de son bien à la suite d'un vol, que par un État dans la même situation... on pourrait également envisager que l'État se substitue à la personne privée qui ne souhaite pas, ou ne peut pas, agir en revendication».

${ }^{41}$ See MAGRI, G. La circolazione dei beni culturali nel diritto europeo: limiti e obblighi di restituzione. Napoli, 2011. p. 38. 
that it was only two years old and, at the same time, the preparatory works on the Convention inspired the drafting of the Directive. It is not surprising, therefore, that there are many points in common between the two texts $^{42}$. The potential overlap between the texts is noted by the Convention itself, in Article 13, providing that «this Convention does not affect any international instrument by which any Contracting State is legally bound and which contains provisions on matters governed by this Convention, unless a contrary declaration is made by the States bound by such instrument». Article 13(3) is even more precise, according to it: «In their relations with each other, Contracting States which are Members of organisations of economic integration or regional bodies may declare that they will apply the internal rules of these organisations or bodies and will not therefore apply as between these States the provisions of this Convention the scope of application of which coincides with that of those rules» ${ }^{43}$. Essentially, according to the so-called "disconnection clause" contained in paragraph 3, EU Member States, which are also members of the Convention, will be allowed to apply the provisions of the Directive which overlap with those of the Convention; on matters not covered by the Directive they will apply the rules provided in the Convention ${ }^{44}$. The

42 See the Rapport explicatif to the Convention (p. 483) «deux initiatives à caractère régional qui ont vu le jour durant les travaux de préparation de la Convention d'Unidroit, qui ont été largement influencées par ceux-ci et ont fourni en retour des références utiles dans les termes des solutions de compromis retenues. Le Règlement CEE n. 3911/92 du Conseil des Communautés européennes du 9 décembre 1992 concernant l'exportation de biens culturels 5 et la Directive 93/7/CEE du Conseil du 15 mars 1993 relative à la restitution de biens culturels ayant quitté illicitement le territoire d'un État membre 6 (et leurs modifications successives) contiennent des mesures de protection pour les patrimoines culturels des États membres de l'Union européenne après l'achévement du Marché intérieur et la suppression des contrôles aux frontières intracommunautaires».

${ }_{43}$ See J. WINTER, J. A. The application of the Unidroit Convention on Stolen or Illegally Exported cultural Objects in Relations between Member States of the European Union. In: DE WAART, Denters e Schrijver (ed.). Reflections on international law from the low countries: in honour of Paul de Waart. The Hague, 1998. p. 347.

44 According to the Rapport explicatif (p. 557) «A la demande de la délégation de l'État détenant alors la présidence du Conseil de l'Union européenne, une clause dite «de déconnexion» a été insérée pour permettre aux États membres d'organisations d'intégration économique ou d'entités régionales de déclarer qu'ils appliquent les règles internes de cette organisation ou entité au lieu de celles de la Convention dont le champ d'application coïncide avec celui de ces règles. Si la proposition initiale visait le cas spécifique des obligations des États membres de l'Union européenne, qui étaient déjà liés entre eux par la Directive 93/7/CEE (applicable aussi entre les États de l'Accord sur l'Espace économique européen), elle a été vue "disconnection clause" has only been invoked by seven of the fourteen EU Member States that have signed the Convention. The question therefore arises as to what will happen if these States were called upon to choose between the Directive (the problem also arises with regard to Directive 2014/60) and the Convention.

The clause nevertheless made it possible to invoke the rules of the Convention to fill any gaps in the Directive. For example, the UNIDROIT Convention could have been used to request the return of goods not covered by Directive 93/7 or to allow the exercise of actions which, under the Directive, were to be regarded as time-barred ${ }^{45}$. With the adoption of the new Directive, however, the application of the two rules, ratione temporis and ratione materiae, has coincided, reducing the possibility of the Convention to fill the gaps in EU legislation.

Moreover, Article 15 of the directive itself (the same provision is foreseen in art. 12 dir. 2014/60) states that its application: «shall be without prejudice to any civil or criminal proceedings that may be brought, under the national laws of the Member States, by the requesting Member State and/or the owner of a cultural object that has been stolen». The rules of national law obviously include those provisions which implement the international agreements and therefore also the UNIDROIT Convention $^{46}$. It follows that under Article 15 (Article 12 of the new directive), in the absence of the adoption of the "disconnection clause", the Convention should prevail over the Directive.

Although there are many similarities between the Convention and the Directive, it is important to note that there are also many differences, which can be traced back to two distinct profiles, one that is formal, linked to the different nature of the two acts, the other one that is of a content type ${ }^{47}$. As regards differences in

comme pertinente pour toute organisation d'intégration économique ou entité régionale qui serait déjà concernée ou pourrait l'être en vertu d'accords qui seraient conclus à l'avenir. Au regard du système de la Convention, les États contractants qui seraient membres d'organisations d'intégration économique ou d'entités régionales sont libres de faire jouer individuellement la clause de déconnexion, par une déclaration à cet effet. Une telle déclaration, à défaut de précision, pourra être faite à tout moment et prendra effet conformément à l'article 15(3)».

45 See MACCARI, A. L.; PIERGIGLI, V. (ed.). Il Codice dei beni culturali e del paesaggio tra teoria e prassi. Milan, 2006. p. 357.

46 See MAGRI, G. La circolarione dei beni culturali nel diritto europeo: limiti e obblighi di restituzione. Napoli, 2011. p. 71,

47 See M. MARLETTA, M. La restituzione dei beni culturali, Normativa comunitaria e Convenzione Unidroit. Padova, 1997. p. 203. 
content, it should be noted that the scope of the Convention is broader than the scope of the Directive. The Convention aims to regulate both the return of illegally exported cultural goods and the return of stolen cultural goods. Furthermore, in the case of stolen goods, the Convention also recognises to private individuals the legitimacy to act to obtain restitution.

The Directive, on the other hand, and given the nature of the act, could not be otherwise, governs only the return of illegally exported cultural goods that is required by EU member States. The Convention, on the contrary, only obliges the States that have signed it. The Directive is subject to the interpretation of the Court of Justice, to which national courts may refer in case of doubts of interpretation, whereas the Convention lacks a body appointed to perform a nomophilactic function. Finally, compliance with the Directive is guaranteed by the effective system of control and sanctions provided for in the Treaties, while the Convention does not provide for any system to monitor its application by part of the contracting States and respect for it remains entrusted to the weakest guarantee mechanisms offered by international law ${ }^{48}$.

Moving on to the comparative analysis of the two texts, we can underline that the directive provides, unlike the Convention, for effective cooperation duties for the Member States which are required to return cultural objects, which go well beyond the mere return of the object and which concern the step preceding the exercise of the action, going so far as to provide for the "good offices" of the central authorities of the requested State, in relation to the owner, in order to facilitate the return of the property to the requesting State.

The Convention is more rigorous in demanding that the requesting State demonstrate to the requested State which primary interests satisfy the restitution of the property, providing for the requesting State to provide evidence of the damage caused by its loss (see art. 5).

Another difference between the two texts can be found in the time limit for bringing the action, which, in the Directive $93 / 7$, is one year and which, on several occasions, has been said to be extended to the three years limit provided for in the Convention in order to allow States to carry out all the activity prior to bringing

48 MARLETTA, M. La restituzione dei beni culturali, Normativa comunitaria e Convenzione Unidroit. Padova, 1997. p. 205. the action ${ }^{49}$. This difference has finally been removed by art. 8 of Directive 2014/60, which increased the time limit for bringing the action to three years.

The Convention's rules are more complicated than those laid down in the Directive with reference to the possessor's diligence requirement for the purpose of paying fair compensation. The Directive merely provides in Article 9 that the court having jurisdiction in the State in which enforcement is sought shall give the possessor a fair compensation according to the circumstances of the case, provided that it is satisfied that the possessor exercised due care and attention in acquiring the object.

The Directive left a certain discretion to the national court in assessing the diligence of the holder. On the contrary, the Convention, taking over the text of the Directive proposal, requires, in general terms, that the possessor must prove that he did not know or should not reasonably have known the unlawful origin of the goods. On this point, the Convention makes a distinction according to whether the goods are stolen or illegally exported. In the first case, Article 4 provides that the possessor is entitled to payment of compensation when the goods are returned, provided that he proves both «neither knew nor ought reasonably to have known that the object was stolen» and that he exercised «due diligence when acquiring the object»; in the case of illicitly exported goods, on the other hand, article 6 requires the possessor to prove that he «neither knew nor ought reasonably to have known at the time of acquisition that the object had been illegally exported». Article 6.3 of the Convention provides instead of compensation, and in agreement with the requesting State, the possessor required to return the cultural object to that State, may decide: to retain ownership of the object or to transfer ownership (against payment or gratuitously) to a person of its choice residing in the requesting State who provides the necessary guarantee. The Directive does not provide for such a choice for the possessor,

49 The European Parliament, in its Resolution dated 12 June 2001, and the Council, in its Resolution of 21 January 2002, noted that the Directive was rather deficient with regard, in particular, to the annual limitation period. They therefore considered it appropriate to encourage the Member States and the European institutions to promote alignment with the three-year limitation period laid down in Article 5(5) of the Unidroit Convention. In the same direction, the 2009 Commission Report. Currently, the limitation period provided for in Directive 2014/60 has been brought into line with that set out in the Convention. 
nor does it address the issue of the attribution of ownership of the returned goods (art. 12). It merely states that the successful bringing of the action entails the return of the property to the territory of the requesting State and that the latter will regulate the attribution of ownership ${ }^{50}$.

The Directive is much more detailed than the Convention in the Rules of Procedure of the proceedings, providing, in Article 5, that it may be presented only if the document initiating it is accompanied by a document describing the object covered by the request and stating that it is a cultural object and a declaration by the competent authorities of the requesting Member State that the cultural object has been unlawfully removed from its territory. The Convention does not go into detail on this point, but merely provides, in Article 5(4), that the requesting State is required to attach to the request «information of a factual or legal nature as may assist the court or other competent authority of the State addressed in determining whether the requirements of paragraphs 1 to 3 have been met».

\section{The influence of the 1995 Convention on Directive 2014/60/EU}

Directive 93/7/EEC has shown little impact in combating illegal trafficking in cultural goods and ensuring their return ${ }^{51}$. The European Union, with the intention of adopting more efficient measures to combat the illegal export of cultural goods, has begun to reflect on possible solutions. The first option would have been to ratify, by the EU, both the 1970 UNESCO Convention and the 1995 UNIDROIT Convention; the second option would have been to promote the ratification of both Conventions in each Member State ${ }^{52}$.

\footnotetext{
50 See MAGRI, G. La circolazione dei beni culturali nel diritto europeo: limiti e obblighi di restituzione. Napoli, 2011. p. 74.

51 See SCHNEIDER, M. The 1995 UNIDROIT Convention: An Indispensable Complement to the 1970 UNESCO Convention and an Inspiration for the 2014/60/EU Directive. Santander Art and Culture Law Review, p. 160, 2/2016.

52 «A possible abrogation could be analyzed only in a context where all Members States would become parties to the UNIDROIT Convention. In such a context, benefits of the Council Directive 93/7/EEC for the return would be less than those offered by the Convention». European Commission Staff Working Document, Impact analysis Accompanying the document Proposal for a Regulation of the European Parliament and of the Council establishing the Copernicus Programme and repealing Regulation (EU) No.
}

These two options, however, proved to be difficult to implement, given the opposition of some Member States. It was then preferred to revise the 1993 Directive, taking into account many of the weaknesses that had emerged over the years and attempting to introduce in its text some rules to bring the reformed text closer to the UNIDROIT Convention. It is therefore not surprising that Directive 2014/60/EU incorporates, almost twenty years later, several features of the UNIDROIT Convention ${ }^{53}$.

It could be noted that, while Directive 93/7 inspired the UNIDROIT Convention, the latter then provided the source of inspiration for reforming the initial model. In this context, the EU Directives and the UNIDROIT Convention are a good example of dialogue between models in an attempt to achieve a common result: the efficient protection of the cultural heritage of individual States.

Directive 2014/60, compared with Directive 93/7, has a wider scope, given that Article 2.1 defines "cultural object" any «object which is classified or defined by a Member State, before or after its unlawful removal from the territory of that Member State, as being among the 'national treasures possessing artistic, historic or archaeological value' under national legislation or administrative procedures within the meaning of Article 36 TFEU». Contrary to the 1993 directive, the concept of cultural property does not depend on whether the property belongs to predetermined categories or to public collections or inventories of ecclesiastical institutions. In this way it is not bound to respect pre-determined limits of age and/or value and can also include goods of palaeontological, ethnographic, numismatic or scientific value which were not previously covered.

Essentially, with the disappearance of the catalogue of cultural objects listed in the Annex to Directive 93/7 and with the extension of protection duties to any object defined as cultural by the individual State, the scope of the Directive expands considerably, leaving it up to the Member States to decide freely how they wish to identify their cultural heritage, exactly as provided for in the UNIDROIT Convention.

\section{1/2010, SWD (2013) 189 final, p. 128}

53 SCHNEIDER, M. The 1995 UNIDROIT Convention: An Indispensable Complement to the 1970 UNESCO Convention and an Inspiration for the 2014/60/EU Directive. Santander Art and Culture Law Review, p. 160, 2/2016. 
The time-limit for bringing an action for restitution has been extended from Article 8(1) to three years (whereas for Article 7 of Directive 93/7 it was one), starting from the date on which the competent central authority of the requesting Member State became aware of the place where the object is located and the identity of its owner or holder. The extension of the time limit for bringing legal proceedings to obtain the return of the property is modelled on the 1995 Unidroit Convention (art. 3 and art. 5) and should facilitate the return and discourage the unlawful removal of property constituting the cultural heritage of the Member States ${ }^{54}$.

In view of the growing illicit trade in cultural goods and, therefore, the need for more effective measures to combat it, there is an even greater need at European level to impose a uniform level of diligence in transactions involving cultural goods in order to deter reckless purchases of goods of illicit origin. In this regard, the system of fair compensation awarded to the possessor of the goods following their return has undergone major innovations compared with the previous system provided for in Article 9 of Directive 93/7. In fact, under Article 10 of Directive 2014/60, compensation may be paid to the possessor, only if he proves his due diligence at the time of purchase of the goods, by verifying the existence of certain criteria expressly indicated, albeit not exhaustively, by Article 10(2). In particular, the so-called "circumstances of the acquisition" must be taken into consideration, such as the "documentation on the object's provenance", the "authorisations for removal required under the law of the requesting Member State", the "character of the parties", the "price paid", "whether the possessor consulted any accessible register of stolen cultural objects" and has assumed "any relevant information which he could reasonably have obtained", or has engaged in "any other step which a reasonable person would have taken in the circumstances" (art. 10.2). The proof of having made the purchase with the necessary due diligence shall be borne by the owner (art. 10, paragraph 1). An innovative approach emerges from the European legislation, which, on the one hand, wanted to standardize the interpretation of the notion of due diligence, providing guidance to the courts in the concrete assessment of the concept, and

54 SCHNEIDER, M. The 1995 UNIDROIT Convention: An Indispensable Complement to the 1970 UNESCO Convention and an Inspiration for the 2014/60/EU Directive. Santander Art and Culture Law Review, p. 160, 2/2016. on the other hand, again with harmonizing intent, has removed the burden of proof from the discipline of the lex fori, and therefore from the different approaches between civil and common law systems, in order to attribute it generally to the possessor.

On the concept of "due diligence and attention" and on the inversion of the burden of proof, which is placed on the possessor, the Directive takes over, almost literally (it only adds the words «authorisations for removal required under the law of the requesting Member State») Article 4.4 of the UNIDROIT Convention $^{55}$. Consequently, it has been pointed out that «the 1995 UNIDROIT Convention actually ends up appearing more "indulgent" in its treatment of acquisitions of illicitly exported cultural objects than the recast of the Directive 2014/60/EU $\gg^{56}$.

\section{Conclusion}

The UNESCO and UNIDROIT Conventions as well as Directive 2014/60 contribute to a certain extent

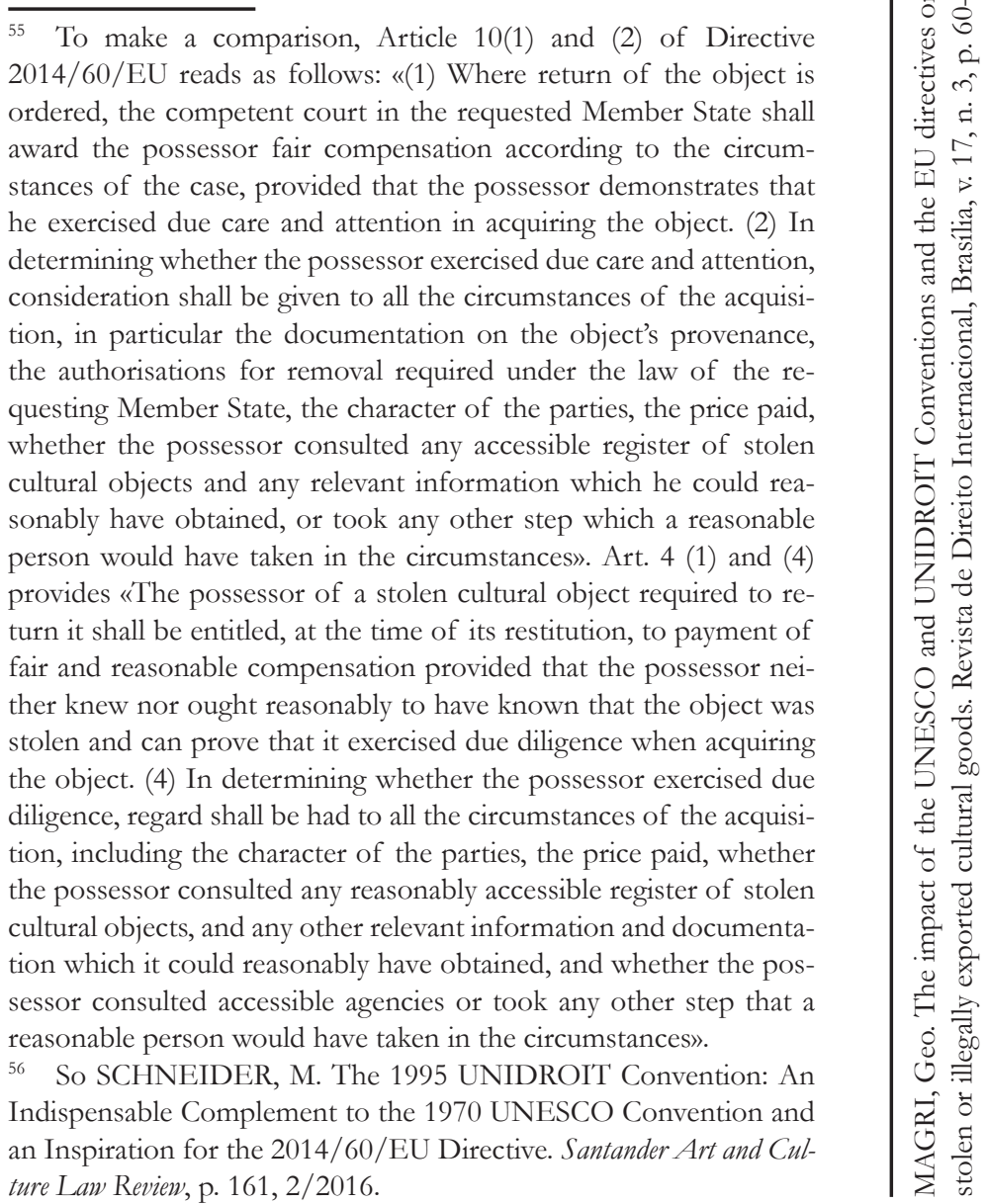


to creating common and minimum legal standards for the return of cultural objects with a view to making the market more transparent. The three legal instruments are closely linked, as their history shows, and have attempted to ensure, albeit at different levels, a common principle: the obligation to protect the cultural heritage of individual states and to return stolen or illegally exported cultural goods.

If we analyse these provisions in the light of their practical results, the achievements do not seem exciting: the UNESCO Convention has been signed by many countries, but its provisions are extremely vague and they make the return of cultural property difficult to implement. The UNIDROIT Convention, on the other hand, contains more detailed provisions on return and restitution actions; this aspect has proved to be its greatest weakness, since it has led many importing states not to sign the Convention. The directive is certainly the most effective legal instrument, but it is also scarcely used in practice. The question that must therefore be asked is: does the lack of use of these legal instruments also means the non-return of illegally exported cultural goods or are they in any case returned to their States of origin? In contrast to what happened in the past, it seems to me that the answer at international level is to regard the theft and illicit circulation of cultural goods as a plague to be fought and eradicated. Even in the absence of specific international obligations, the return of stolen or illicitly exported cultural goods is becoming an increasingly widespread practice.

In Italy among the many works that have returned thanks to diplomatic agreements, we can remember the Euphronios Krater (conserved in the United States) and the "Vase of Flowers" by Jan van Huysum (brought to Germany during the Second World War).

Particularly significant is the case of the Euphronios Krater which was exhibited at the Metropolitan $\mathrm{Mu}-$ seum in New York and which had been purchased by a dealer who had received it from Italian grave robbers. The fact that a famous museum refuses to keep in its collection an object of illicit provenance and agrees to return it, even in the absence of mandatory legal obligations, shows how the principles that the UNESCO and UNIDROIT Conventions have introduced are now well established and proves that these provisions, even if not concretely applied, have contributed to a radical change of perspective in mentality. If once museums were competing for the most valuable objects, often accepting even objects of dubious or clearly illicit provenance, today they are much more careful in verifying the legitimacy of the provenance and are inclined to return what was stolen in the past, considering their behaviour as a form of contribution to the conservation of the cultural heritage of other countries and, indirectly, of the whole of humanity.

Another demonstration of a change of mentality in the art market and in the management of museums, which attests to the spreading of the principle that the illicit circulation of cultural goods must be contrasted, is shown by the increasing diffusion of soft law texts and codes of conduct. These rules, which are directly derived from traders and museums, impose stronger control over the licit origin of cultural goods. In this sense, we can recall both the ICOM's code of ethics and the initiative, created in Switzerland, to encourage the creation of rules that guarantee a responsible art market (RAM Initiative).

The rules on the return of cultural property also have an impact on private law. The legal literature has begun to reflect on whether the restitution duties affect the applicability of the rules on bona fide purchase contained in many codifications of civil law countries. This reflection has been particularly developed in Italy, where Article 1153 of the Civil Code provides for a particularly broad protection of bona fide purchasers that includes even stolen goods. The legal literature ${ }^{57}$, on the basis of the UNESCO and UNIDROIT Conventions, as well as the provisions of EU law, has begun to wonder whether, with reference to cultural goods, such protection of the purchaser is still desirable and compatible with the obligations imposed on Italy as a Contracting State of the two Conventions and a member of the EU. It is reasonable to assume that such perplexities are also echoed in Italian jurisprudence, which should be particularly rigorous in applying article 1153 of the Italian Civil Code to cultural goods.

If we have to draw a conclusion from the Unesco and Unidroit Conventions and from Directive 2014/60, it seems to me that we should not look at the number of cases in which these rules have been applied, but rather at the impact that these rules have had on the mindset

\footnotetext{
57 See MAGRI, G. Acquisto a non domino e beni culturali. Riv. dir. civ., p. 741, 2013. and SACCO, R.; CATERINA, R. Il possesso. Milan, 2014.
} 
of legal practitioners and on the art market. One might question whether, in this case, the legislation was a forerunner or an epigone of a change of perspective. I believe that the conventions (especially the UNESCO Convention) have anticipated a change in mentality, helping to formalise it. The presence of precise legal rules, although little used, has undoubtedly facilitated and influenced a more responsible approach to cultural heritage. Fifty years after the adoption of the UNESCO Convention and twenty-five years after the UNIDROIT Convention, we can therefore say that the duty to return stolen or illicitly exported cultural goods to their State of origin has become widespread at global level and has even been accepted by countries that are not parties to these conventions or to situations not covered by their scope of application.

\section{References}

BERGE, J.S. La Convention d'UNIDROIT sur les Biens Culturels: Retour sur un Texte Majeur dans la Lutte Contre un Fait International Illicite de Circulation. Uniform Law Review, v. 20, Issue 4, p. 535, 2015.

BYRNE-SUTTON, Q. The Goldberg Case: A Confirmation of the Difficulty in Acquiring Good Title to Valuable Stolen Cultural Objects. International Journal of Cultural Property, p. $151,1992,1^{\text {st. }}$.

CARDUCCI, G. Complémentarité entre les Conventions de l'UNESCO de 1970 et d'UNIDROIT de 1995 sur les biens culturels. Uniform Law Review / Revue de droit uniforme, v. 11, p. 93, 2006.

CARDUCCI, G. La restitution internationale des biens culturels et des objets d'art. Droit commun, Directive CEE, Convention de l'UNESCO et d'UNIDROIT. Paris: LGDJ, 1997.

DELEPIERRE, S.; SCHNEIDER, M. Ratification and Implementation of International Conventions to Fight Illicit Trafficking of Cultural Property. In: DESMARAIS, F. (ed.). Countering Illicit Traffic in Cultural Goods: The Global Challenge of Protecting the World's Heritage, ICOM International Observatory on Illicit Traffic in Cultural Goods. Paris, 2015. p. 130.

FRIGO, M. Circulation des biens culturels, détermination de la loi applicable et méthodes de règlement des litiges. Recueil des Cours de l'Académie de la Haye, , v. 375, p. $267,2014$.
FRIGO, M. La circolazione internazionale dei beni culturali, Diritto Internazionale, Diritto Comunitario e Diritto Interno. II ed. Milan, 2007.

FRIGO, M. La Convenzione dell'Unidroit sui beni culturali rubati o illecitamente esportati. Riv. dir. int. priv e proc., p. 435, 1996.

GABBRIELLI, V. Patrimoni contesi: gli stati italiani e il recupero delle opere d'arte trafugate in Francia: storia e fonti: 1814-1818. Firenze, 2009.

GARDELLA, A. Nuove prospettive per la protezione internazionale dei beni culturali: la Convenzione dell'UNIDROIT del 24 giugno 1995. Dir. Comm. Int., p. 997, 1998.

GRAZIADEI, M.; PASA, B. in A. JAKUBOWSKI, K. HAUSLER, F. FIORENTINI (ed.). Cultural Heritage in the European Union: A Critical Inquiry into Law and Policy. Leiden - Boston, 2019. p. 88.

JAYME, E. Globalization in Art Law: Clash of Interests and International Tendencies. Vanderbilt Journal of Transnational Law, p. 928, 2005.

JAYME, E. Internationaler Kulturgüterschutz: Lex originis oder lex rei sitae. Tagung. Heidelberg, in IPrax, n. 10, p. $347,1990$.

JAYME, E.; WAGNER, F. D. Kulturgüterschutz und Privatrecht: Die UNIDROIT-Konvention von 1995. Tagung des Ludwig Boltzmann Instituts für Europarecht. Wien, IPrax, v. 17, p. 140, 1997.

KOWALSKI, W. Ratification of the 1995 UNIDROIT Convention on Stolen or Illegally Exported Cultural Objects, in Light of Directive 2014/60/UE on the Return of Cultural Objects Unlawfully Removed from the Territory of a Member State: The Perspective of Poland. Santander Art and Culture Law Review, p. 165, 2/2016.

MACCARI, A. L.; PIERGIGLI, V. (ed.). Il Codice dei beni culturali e del paesaggio tra teoria e prassi. Milan, 2006.

MAGRI, G. Acquisto a non domino e beni culturali. Riv. dir. civ., p. 741, 2013.

MAGRI, G. Directive 2014/60/EU and Good Faith Acquisition of Cultural Goods. in Italy. In: PINTON, S.; ZAGATO, L. (ed.). Sapere l'Europa, sapere d'Europa Cultural Heritage. Scenarios, 2015-2017. v. 4. p. 227.

MAGRI, G. La circolarione dei beni culturali nel diritto europeo: limiti e obblighi di restituzione. Napoli, 2011. 
MARLET'TA, M. La restituzione dei beni culturali, Normativa comunitaria e Convenzione Unidroit. Padova, 1997.

MENGONI, L. Gli acquisti a non domino. Milan, 1994.

MIUR WATT, O. La revendication internationale des biens culturels: à propos de la décision américaine Eglise Autocéphale. Rev. crit. droit int. privé, p. 1, 1992.

O'KEEFE, P. J. Commentary on the UNESCO 1970 Convention on Illicit Traffic. Leicester 2000.

PRO'T'T, L. V. The UNIDROIT Convention on stolen or illegally exported cultural objects - Ten Years On, in Uniform Law Review. Revue de droit uniforme, p. 215, 2009 .

SACCO, R.; CATERINA, R. Il possesso. Milan, 2014.

SALIBA, A.; FABRIS, A. L. O retorno de bens culturais. Revista de Direito Internacional, v. 14, n. 2, p. 491, 2017.

SALVADORI, M. Profili internazionalistici. In: I nuovi contratti nella prassi civile e commerciale, a cura di Cendon. Turin: Beni culturali, 2003. v. VII. p. 401.
SCHNEIDER, M. The 1995 UNIDROIT Convention: An Indispensable Complement to the 1970 UNESCO Convention and an Inspiration for the 2014/60/EU Directive. Santander Art and Culture Law Review, p. 152, $2 / 2016$.

SPRECHER, J. Beschränkungen des Handels mit Kulturgut und die Eigentumsgarantie. De Gruyter, 2004.

SYMEONIDES, S. C. Choice of Law Rule for Conflicts Involving Stolen Cultural Property. Vanderbilt Journal of Transnational Law, p. 1177, 2005.

TURNER, S. Das Restitutionsrecht des Staates nach illegaler Ausfubr von Kulturgütern. De Gruyter, 2002.

VON BAR, C. Gemeineuropä̈sches Sachenrecht. Munich, 2019. v. 2.

WINTER, J. A. The application of the Unidroit Convention on Stolen or Illegally Exported cultural Objects in Relations between Member States of the European Union. In: DE WAART, Denters e Schrijver (ed.). Reflections on international law from the low countries: in honour of Paul de Waart. The Hague, 1998. p. 347. 
Para publicar na Revista de Direito Internacional, acesse o endereço eletrônico www.rdi.uniceub.br ou www.brazilianjournal.org.

Observe as normas de publicação, para facilitar e agilizar o trabalho de edição. 